\title{
The Brexit Referendum - Legal aspects
}

Béatrice Schütte (schuette.beatrice@gmail.com) Aarhus University, Denmark

The result of the Brexit referendum was that the UK voted to leave the European Union (EU). The UK government must now invoke Article 50 of the Treaty on the European Union (TEU), which regulates the voluntary withdrawal of a Member State from the EU. However, there is significantly more to this process than the mere exit procedure. A country's withdrawal has legal, political, institutional and economic consequences not only for the departing Member State but also for the EU and for the citizens in question. Institutional compositions will change. In the UK, existing legislation influenced by EU law may need to be amended. Regulatory gaps that emerge when EU law ceases to apply will need to be filled. The future relationship between the EU and the UK will have to be negotiated. Both EU citizens living in the UK and UK citizens living in other Member States will probably face bureaucratic obstacles. This paper gives an overview of the legal considerations relating to Brexit.

\section{Introduction}

On 23rd June, the referendum held in the United Kingdom on the question of whether the country should remain a member of the European Union (EU) ended with a small majority in favour of 'leave'. Despite criticism stemming from the tight result, and notwithstanding the fact that referenda are not binding under British law, new Prime Minister Theresa May said she felt bound by the decision and would guide the country through the Brexit procedure. ${ }^{1}$ The tight result was not the only contentious issue. It has been argued that UK citizens were not sufficiently informed about the potential economic consequences of Brexit. Surveys also showed that the general public had a rather poor knowledge of EU institutions - a finding supported by the fact that on the day following the referendum, the second most frequent Google query in the UK was 'What is the EU?'. ' Some have argued that if the country withdraws from the EU but remains a part of the internal market, it will still be subject to EU law but no longer be able to exert influence on its future development. ${ }^{3}$ This was the second referendum on EU membership to have taken place in the UK. The first was in 1975, only two years after the country's accession to what was then called the European Economic Community. This referendum ended with a two-thirds majority in favour of remaining a Member State. ${ }^{4}$ The result of the present referendum seems a logical and unsurprising culmination of growing Euroscepticism in many of the Member States. The people's poor knowledge of the EU and its institutions, as mentioned above, as well as a lack of access to and understanding of actions taken in Brussels, led to a breakdown in trust among UK citizens that resulted in the decision to leave.

\footnotetext{
${ }^{1}$ http://www.express.co.uk/news/politics/683178/Brexit-is-EU-referendum-legally-binding-what-Article-50-legalprocess-Britain-leave (retrieved 5 November 2016).

${ }^{2}$ Welfens (2016), p. 540.

${ }^{3}$ Deutscher (2016) p. 2.

${ }^{4}$ Welfens (2016), p. 539.
} 
People both inside and outside of the UK are now wondering what the future holds. Politicians from other EU Member States have repeatedly claimed that the process should be initiated quickly. However, the practical aspects of such a move are complex. This is the first ever application of Article 50 - a provision that is relatively new. Equally, Article 50 has been criticised for its incomplete detailing of the procedure, leaving gaps that must be filled by lawyers and politicians. ${ }^{5}$ Time will tell whether Article 50's theoretical mechanisms are feasible in practice.

\section{Voluntary Withdrawal from the European Union}

The 2009 Treaty of Lisbon gives Member States the possibility to voluntarily withdraw from the EU. None of the earlier treaties contained such a provision. Before 2009, the question of whether Member States had a right to exit the EU was highly disputed among legal academics. Against the right to terminate membership, it was argued that the treaties were concluded for an unlimited period, as per the current Article 53 TEU and Article 356 TFEU. On the other hand, given that EU membership is voluntary ${ }^{6}$, the subsidiary applicability of public international law as well as the sovereignty of the Member States were thought to favour the right to voluntary withdrawal ${ }^{7}$. However, the introduction of the Treaty of Lisbon put an end to this discussion.

\subsection{Article 50 TEU Withdrawal Procedure}

Article 50 I of the Treaty on the European Union (TEU) states that any Member State may, in accordance with its own constitutional requirements, decide to exit the EU. There are no further substantive requirements for a withdrawal. A Member State wishing to leave the EU need not give any particular reason. 'Voluntary' also means that no consent of the other Member States is required. ${ }^{8}$ Article 50 TEU stresses the Member States' continuous sovereignty in relation to the EU. Not only are these states the 'Master of the Treaties' as expressed in Articles 48 and 54 TEU but they are also the masters of their own membership. The provision also refers to the constitutional requirements of the Member States. This reference is generally seen as merely declaratory, as compliance with national law is not a matter of EU law. Whether these requirements are met can therefore only be determined by the withdrawing Member State and not by the ECJ or other Member States. An exception to this might be Germany, as Article 23 of the Grundgesetz ${ }^{9}$ includes the duty to contribute to European integration. ${ }^{10}$ A German withdrawal without substantial reasons may hence be deemed unconstitutional. ${ }^{11}$

The exit procedure is regulated by Article 50 II TEU. The withdrawing Member State must announce its intention to the European Council. However, the provision does not state any formal requirements regarding this notification. The EU and the Member State must then negotiate a treaty concerning the details of the exit and future relations between the Member State and the EU. This must be done according to Article 218 III TFEU, which regulates the conclusion of international agreements by the EU. All decision-making

\footnotetext{
${ }^{5}$ Lazowski (2016), p. 1.

${ }^{6}$ The German Federal Constitutional Court classified the EU as a 'Staatenverbund', a voluntary association of states in order to reach common goals; Blanke, Mangiameli (2013), Article 50, marginal no. 6.

${ }^{7}$ Grabitz, Hilf, Nettesheim (2016), Article 50 TEU, marginal no. 1.

${ }^{8}$ Blanke, Mangiameli (2013), Article 50, marginal nos. 24, 25.

${ }^{9}$ Basic Law, the German Constitution.

${ }^{10}$ Blanke, Mangiameli (2013), Article 50, marginal no. 25; von der Groeben, Schwarze, Hatje (2015), Article 50, marginal no. 9.

${ }^{11}$ Callies, Ruffert (2016), Article 50 TEU, marginal no. 4.
} 
institutions are involved. ${ }^{12}$ The agreement should also deal with concrete questions such as mutual compensation, the future of pending cases at the ECJ, pending administrative procedures, the withdrawing Member State's contributions to current projects, and its participation in decision-making institutions during the exit procedure. ${ }^{13}$ Negotiations are based on guidelines determined by the European Council. Representatives of the withdrawing Member State are not involved in any decisions. If the EU treaties do not contain specific provisions, the law applicable to the treaty between the departing Member State and the EU is the general Public International Law. ${ }^{14}$

According to Article 50 III TEU, EU treaties cease to apply to the Member State from the day the exit treaty enters into force, or two years from the date of the declaration being made to the European Council. The exiting Member State may, however, with the agreement of the European Council, decide to extend this timeframe. The treaty is not a constitutive requirement for an exit from the EU - a Member State can also leave without this framework. Due to the manifold legal, political and economic consequences of a Member State's withdrawal, however, this hardly seems feasible. ${ }^{15}$ One of the consequences of a Member State leaving is a change in the composition of EU institutions such as the European Parliament, the European Commission, the European Council, and the European Court of Justice.

\subsection{Possible Exclusion from the European Union}

Shortly after the referendum, politicians from other Member States repeatedly claimed that the process should be initiated as swiftly as possible. On the one hand, it is understandable that the remaining Member States want legal and political security; on the other, the complex, time-consuming nature of the process should be taken into account. It has been argued that the strict attitude towards the UK is related to the fact that there are parliamentary elections in Germany in 2017, as well as presidential elections in France. ${ }^{16}$ However, the demand for a swift Brexit raises another question: If the process does not start quickly enough, or if the UK parliament ends up preventing Article 50 TEU from being invoked, could the UK still be excluded from the EU?

Under the scope of Article 50 TEU, the withdrawing Member State cannot be formally forced to invoke the provision and no deadline can be set to do so. ${ }^{17} \mathrm{EU}$ treaties, equally, do not contain any provision for facilitating a Member State's exclusion. Nevertheless, in September 2016, the Minister of Foreign Affairs of Luxembourg, Jean Asselborn, demanded Hungary's exclusion due to the country's treatment of refugees. ${ }^{18}$

Under the scope of the EU treaties, Article 7 III TEU allows for the temporary suspension of certain rights in cases of persistent and serious breach of the values mentioned in Article 2 TEU. ${ }^{19}$ Exclusion from a treaty, however, is only possible under the scope of general Public International Law. It is a matter of debate among academics whether these rules are applicable or whether the body of EU law is exhaustive. Some academics argue that the respective provisions of the EU treaties are lex specialis, and that there is

\footnotetext{
${ }^{12}$ Blanke, Mangiameli (2013), Article 50, marginal no. 27.

${ }^{13}$ von der Groeben, Schwarze, Hatje (2015), Article 50, marginal no. 5.

${ }^{14}$ Grabitz, Hilf, Nettesheim (2016), Article 50 TEU, marginal no. 9; Blanke, Mangiameli (2013), Article 50, marginal no. 28.

${ }^{15}$ Callies, Ruffert (2016), article 50 TEU, marginal no. 5.

${ }^{16}$ Hammond (2016), p. 508.

${ }^{17}$ Lazowski (2016), p. 1.

${ }^{18}$ http://www.spiegel.de/politik/ausland/fluechtlinge-jean-asselborn-fordert-eu-ausschluss-von-ungarn-a1112024.html (retrieved 8 November 2016).

${ }^{19}$ Article 2 TEU refers to the following values: respect for human dignity, freedom, democracy, equality, the rule of law and respect for human rights including the rights of persons belonging to minorities.
} 
no possibility to fall back on Public International Law such as the Vienna Convention on the Law of Treaties. ${ }^{20}$ This is supported by the argument that the flexible regulation of Article 7 TEU offers a powerful means of exerting pressure on a Member State in breach of fundamental values. Others argue that if all measures under the scope of Article 7 TEU fail, and a state persistently damages the EU's reputation, the treaties could be interpreted as meaning that the other Member States would not be bound forever to a state that constantly violates fundamental EU values and damages the reputation of both the Union and its members. ${ }^{21}$ However, the exertion of rights granted in the Treaty, such as voluntary withdrawal and any preparatory procedures, could never constitute a serious and persistent breach of fundamental values. Even if the Brexit procedure takes much longer than foreseen Member States - or in the improbable event that it does not happen at all - this would not be deemed a reason to exclude the UK from the EU.

\section{Legal Aspects Beyond Article 50 TEU}

There are a number of legal aspects to consider regarding the withdrawal procedure that extend beyond Article 50 TEU as such.

\subsection{Consent of Parliament}

The UK government wanted to invoke Article 50 TEU without a parliamentary vote. On 3 November 2016, however, the British High Court ruled that Parliament must vote and that the government does not have prerogative powers in this matter. The government has announced its intention to appeal the decision, and the Supreme Court may have the final say. Brexit supporter Nigel Farage fears an attempt to block the country's withdrawal from the EU. ${ }^{22}$ Regardless of the outcome to this legal challenge, it seems that if and when Article 50 TEU is invoked, the withdrawal process will be complex and drawn out. As such, the two-year timeframe may not be realistic.

\subsection{Influence of Brexit on the Law in Force in the UK}

The body of EU law in force consists of roughly 21,000 regulations and directives ${ }^{23}, 1,100$ international agreements concluded by the $\mathrm{EU}^{24}$, court decisions by the $\mathrm{ECJ}$, as well as numerous guidelines and other soft law instruments, the exact number of which is hard to define as no institution publishes official numbers ${ }^{25}$. Not all of these affect the UK. From the day the withdrawal becomes valid, however, none of the provisions binding the country will continue to apply. The country will possibly need to enact corresponding national legislation in order to avoid regulatory gaps. The EU directives are not a major problem in this context, as they must be implemented into national law to have effect. Still, it may be necessary to revise or amend at least a part of these directives to cater for the new relationship between the UK and the EU. EU regulations, which are directly applicable, may pose the bigger problem. The most relevant act to be repealed is the European Communities Act, according to which the UK acknowledges the supremacy of EU law. ${ }^{26}$

Regarding the applicability of international treaties, a distinction must be drawn between those in the field of the EU's exclusive competence and the mixed agreements signed by

\footnotetext{
${ }^{20}$ Grabitz, Hilf, Nettesheim (2016), Article 50, marginal no. 12.

${ }^{21}$ Von der Groeben, Schwarze, Hatje (2015), Article 50, marginal no. 15.

${ }^{22}$ http://www.bbc.com/news/uk-politics-37857785 (retrieved 3 November 2016).

${ }^{23}$ http://www.n-tv.de/politik/Die-Wahrheit-ueber-die-Regelungswut-der-EU-article12821446.html (retrieved 7 November 2016).

${ }^{24}$ Van der Loo, Blockmans (2016).

${ }^{25}$ http://en.euabc.com/word/2152 (retrieved 8 November 2016).

${ }^{26}$ Lazowski (2016), p. 2.
} 
both the EU and its Member States. ${ }^{27}$ Treaties in the field of the EU's exclusive competence will cease to apply in the UK once the withdrawal process is completed. If the country wishes to uphold the relationship in question, the agreement must be renegotiated, with the UK as a contracting party. Mixed agreements are more complicated. These deal with issues where the EU has exclusive competence, as well as issues whose competence falls to the Member States. For the latter, special arrangements will have to be made between the EU, the UK and the other contracting states for the treaty in question. $^{28}$

\subsection{The Future Relationship between the UK and the EU}

The treaty must also contain a concept of the new relationship between the UK and the EU. For instance, whether the UK wants to remain a member of the European Economic Area (EEA); whether they might aim for a Norwegian, a Swiss, a Canadian or a Turkish solution; whether they might opt for a WTO model; ${ }^{29}$ or whether the solution may be something new and without precedent. The Norwegian model would still provide the UK with full access to the internal market, as the country would remain a member of the EEA. To do so, however, the UK would have to accept free movement of citizens and of services as well as standards on health and safety determined in Brussels, without having any influence in the decision-making process. The Norwegian model also includes contributions to the EU budget. ${ }^{30}$ Some of the main arguments cited by the 'leave' campaign related to stopping the free movement of citizens and ending the supremacy of EU law including over-regulation and over-intervention, as well as opposition to trade agreements concluded by the EU. These factors make the adoption of the Norwegian model rather improbable. ${ }^{31}$ The Swiss model implies that there would be multiple agreements with the EU, as Switzerland is not a member of the EEA. The Turkish solution would entail a customs union by which exports could pass freely into the EU without being subject to customs controls. The Canadian model would use CETA as a template. ${ }^{32}$ Over the past 40 years, several areas of British law have been developed in accordance with European law. The examination of the necessary changes will be a costly and time consuming process. Brexit will also directly affect both EU citizens living in the UK as well as UK citizens living in other EU member states. When the withdrawal process is completed, free movement of citizens will no longer apply. ${ }^{33}$ It may then be mandatory for UK citizens in the EU and for EU citizens in the UK to apply for residence and work permits unless specific arrangements are made in the treaty to be concluded between the EU and the UK - an outcome that appears improbable, as one of the objectives of Brexit was to mitigate immigration from other Member States to the UK. It is therefore unsurprising that applications for citizenships of other Member States made by UK citizens significantly increased after the referendum. ${ }^{34}$

\section{Re-accession to the EU by Scotland and Northern Ireland?}

Developments in those parts of the UK where the majority voted in favour of remaining will be particularly interesting to observe. Even before the referendum, Scottish

\footnotetext{
${ }^{27}$ Van der Loo, Blockmans (2016).

${ }^{28}$ Van der Loo, Blockmans, (2016).

${ }^{29}$ Hammond (2016) p. 509; Emerson (2016), p. 1.

${ }^{30}$ Emerson (2016), p. 3.

${ }^{31}$ De Grauwe (2016), p. 250; James (2016) p. 524.

${ }^{32}$ Emerson (2016), pp. 4-8.

${ }^{33}$ Deutscher (2016), p. 4/5.

${ }^{34}$ Deutscher (2016), p. 5.
} 
politicians had discussed a second independence referendum in the event that Brexit became a reality. Post-independence, a new state would have to go through the general accession procedure regulated by Article 49 TEU. To apply for accession, a state must belong to the European area. Another substantive requirement is the fulfilment of the so-called Copenhagen Criteria adopted in 1993 by the European Council in preparation for the Eastern enlargement of the EU. The Copenhagen Criteria include: institutional stability guaranteeing democracy and the rule of law, the preservation of human rights, and the protection of minorities; a functioning market economy; and the capability to take on the duties arising from the membership and to adopt the goals of the economic and monetary union. ${ }^{35}$ As these criteria are already met by the UK, however, they should also be met by Scotland and Northern Ireland.

\section{Conclusion}

Given the length of time it takes to draft other less complex, single-issue international agreements, the two-year timeframe for Brexit appears tight. It hence seems probable that both sides will have to agree on a prolongation as facilitated in Article 50 III TEU. To prevent the EU from falling apart, Member States will need to take a strong stance when negotiating agreements with the UK. To do otherwise would be to indicate that remaining Member States may withdraw from the EU and its perceived inconveniences, while retaining the advantages of membership.

\section{References:}

Blanke, H.-J., Mangiameli, S. (eds.) (2013). The Treaty on the European Union - A Commentary. Heidelberg, New York: Springer

Callies, C., Ruffert, M. (2016). EUV/AEUV. $5^{\text {th }}$ ed. Munich: C.H. Beck

De Grauwe, P. (2016.) What Future for the EU after Brexit? Intereconomics 51, 249-251. DOI: $10.1007 / \mathrm{s} 10272-016-0612-0$.

Deutscher, E. (2016). Exit. European Journal of Legal Studies, 9, 1-9.

Emerson, M. (2016) Which Model for Brexit? CEPS Special Report No. 147, October 2016 Grabitz, E., Hilf, M., Nettesheim, M. (2016) Das Recht der Europäischen Union, Munich: C.H. Beck.

Hammond, J. (2016) Brexit - Die rechtliche Dimension eines EU-Austritts. IWB Internationales Steuer- und Wirtschaftsrecht, 508-510.

James, H. (2016) Britain and Europe - what ways forward? International Economics and Economic Policy, 523-530.

Lazowski, A. (2016) Procedural Steps towards Brexit. CEPS Commentary Series, July 2016. https://www.ceps.eu/publications/procedural-steps-towards-brexit, $\quad$ retrieved 7 November 2016.

Van der Loo, G., Blockmans, S. (2016). The Impact of Brexit on the EU's International Agreements,

CEPS Commentary Series https://www.ceps.eu/publications/impact-brexiteu\%E2\%80\%99s-international-agreements, retrieved 7 November 2016.

Von der Groeben, H., Schwarze, J., Hatje, A. (2015). Europäisches Unionsrecht. $7^{\text {th }}$ ed. Baden-Baden: Nomos Verlagsgesellschaft

Welfens, P. (2016). Cameron's Information Disaster in the Referendum of 2016: an Exit from Brexit? International Economics and Economic Policy, 539-548. DOI 10.1007/s10368-016-0361-3

${ }^{35}$ Grabitz, Hilf, Nettesheim (2016), Article 49 TEU, marginal no. 17. 